
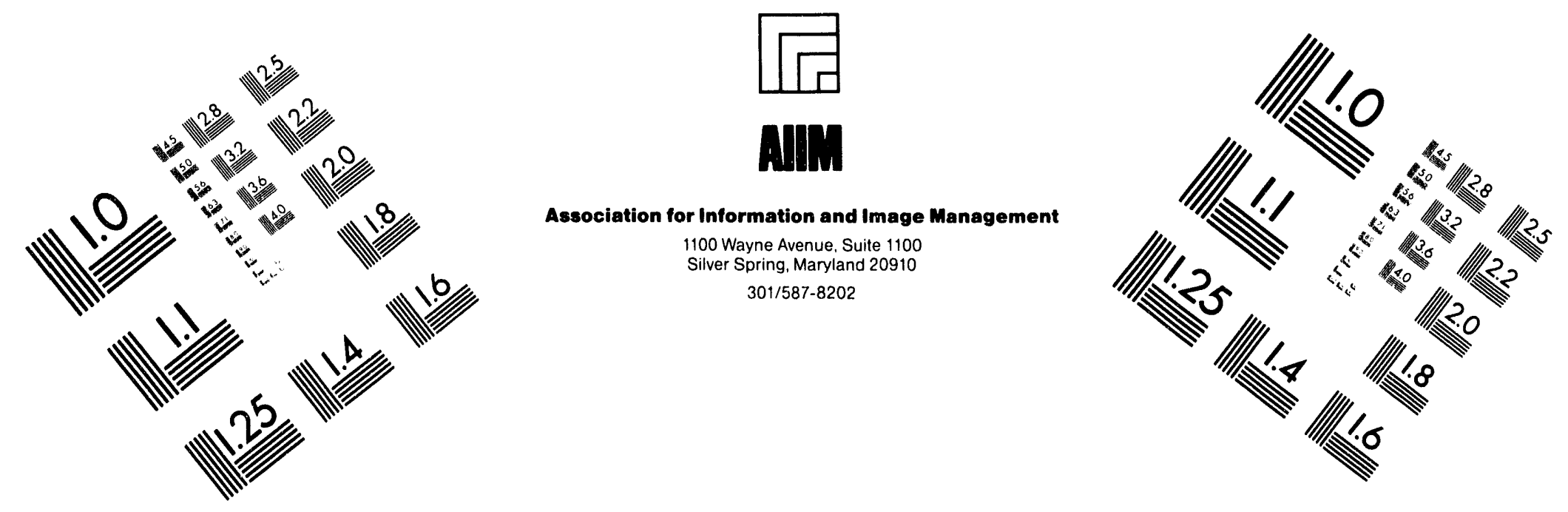

\title{
Centimeter
}

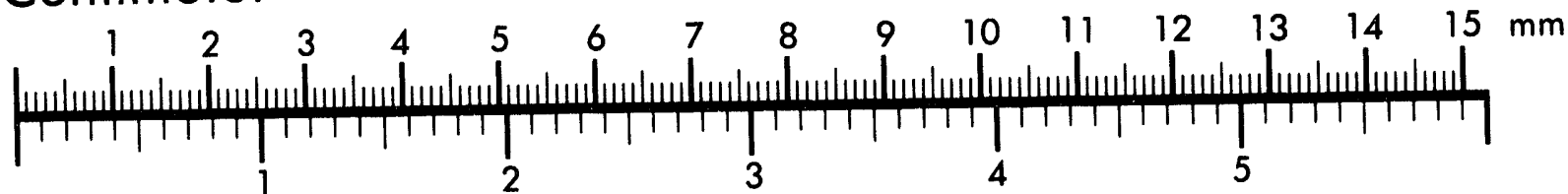
Inches
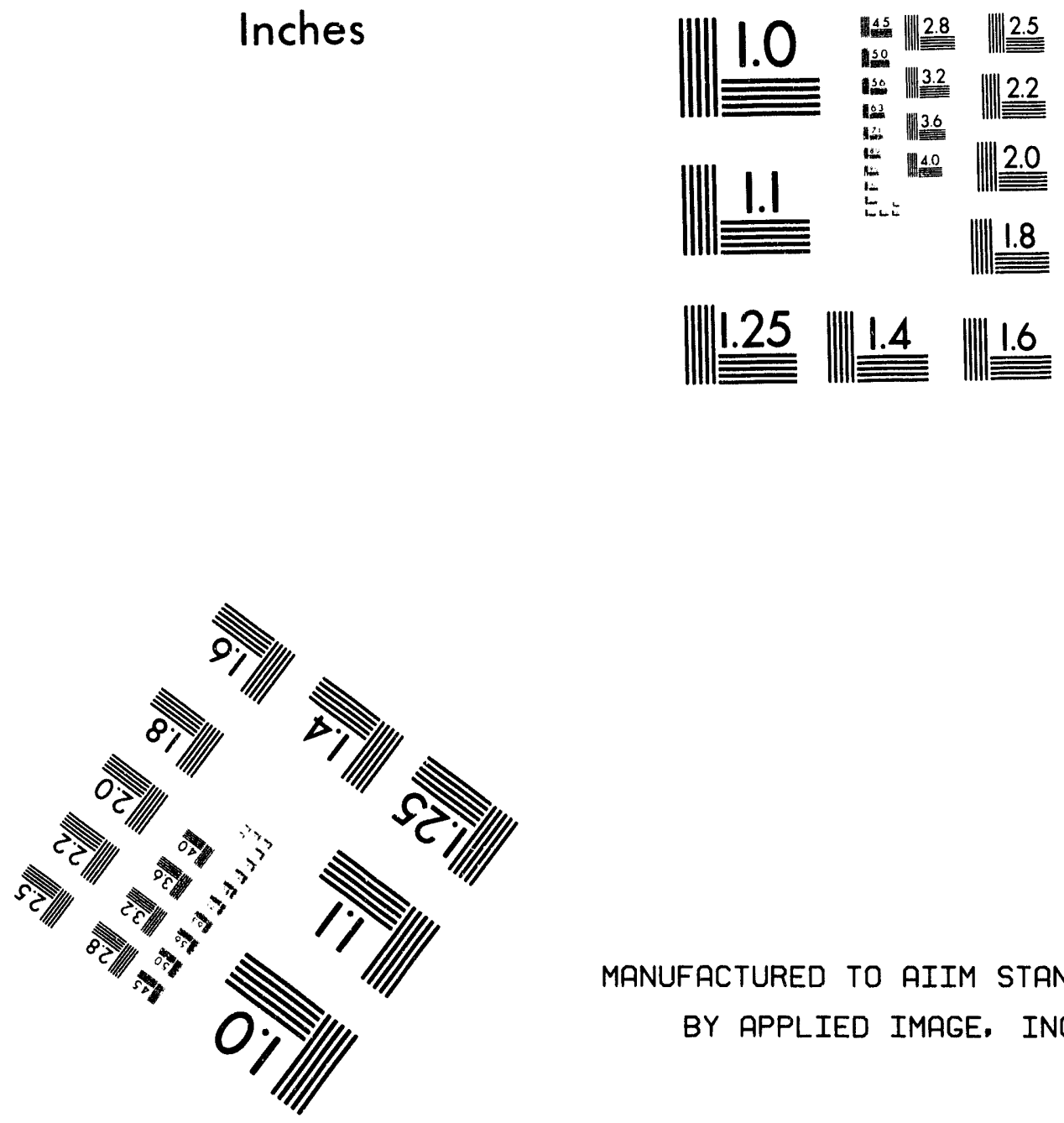

MANUFACTURED TO AIIM STANDARDS BY APPLIED IMAGE. INC.

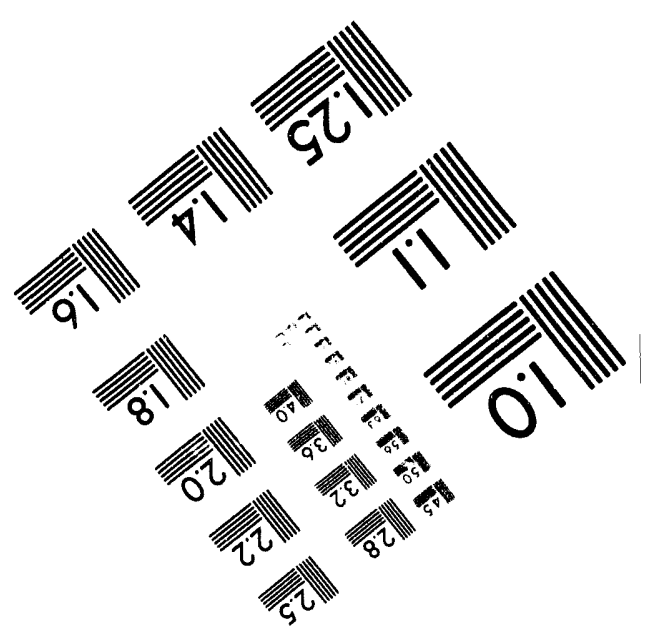



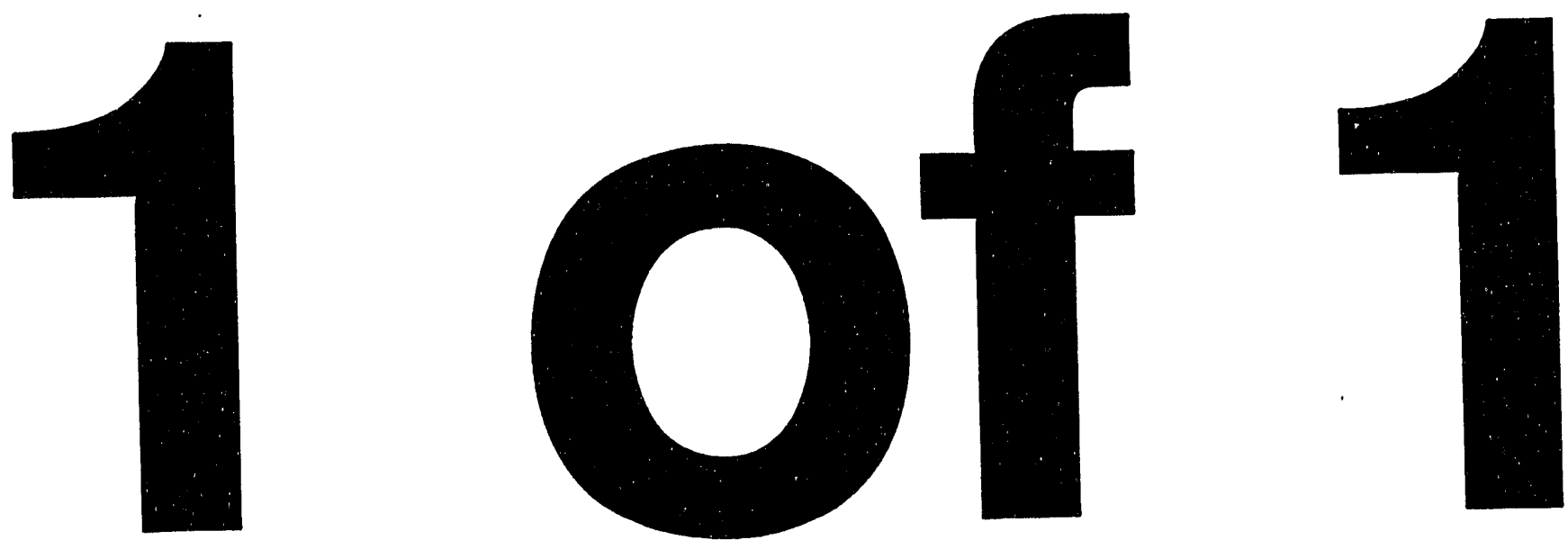


\title{
CONF-931108--100
}

UCRL-JC-116132

PREPRINT

\section{Constraints on the Affinity Term for Modeling Long-Term Glass Dissolution Rates}

\author{
William L. Bourcier \\ Susan A. Carroll \\ Brian L. Phillips
}

RECEIVED

MAY 231994

OSTI

This paper was prepared for submittal to the

Materials Research Society

Boston, $M A$

November 29 - December 3, 1993

November 1993

This is a preprint of a paper intended for publication in a joumal or proceedinga. Since changes may be made before publication, this preprint is made available with the understanding that it will not be cited or reproduced without the permission of the author.

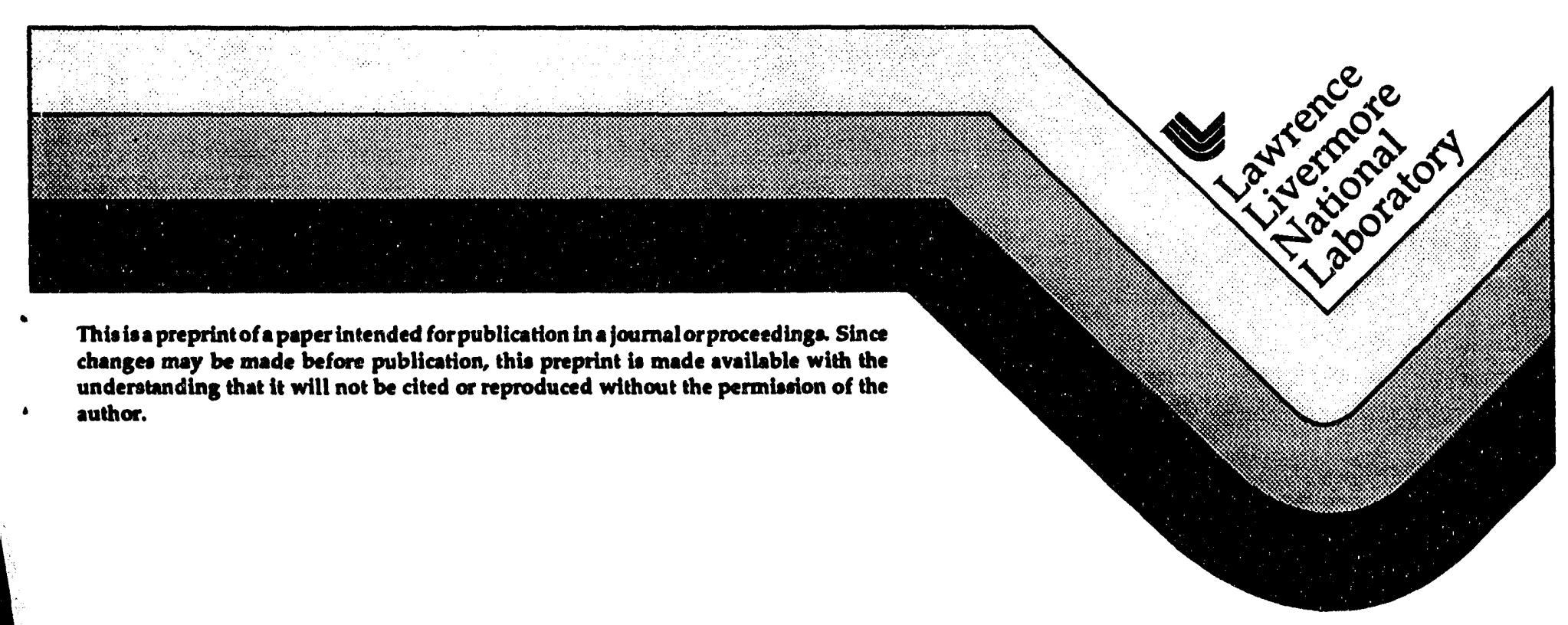




\section{DISCLAIMER}

This document wa prepared an an scoound of worts sponsoned by an agency of the United States Government. Netther the United States Government nor the Univervity of Callfornia nor any of their smployees, makes any warranty, express or implied, or asoumes any legal tiability or respondibility for the aceuracy, completeness, or wefulnes: of any information, spparntes, prodect, or process discloced, or represents that its use would not infringe privalely owned righte. Reference herein to any epecific commercial products, proceses, or service by trade name, trademart, menufacturer, or otherwise, does not becesearily cometitute or imply its endorneweut, necommendation, or favoring by the Uniled Stcles Government or the Univeraity of California. The views and opinione of authors expresed herein do not necesaarily atate or reflect those of the United States Government os the Univeratty of Californis, and shell not be used for advertising or product endorsement purposes. 


\section{CONSTRAINTS ON THE AFFINITY TERM FOR MODELING LONG-TERM GLASS DISSOLUTION RATES}

WILLIAM L. BOUP IIER, SUSAN A. CARROLL, AND BRIAN L. PHILLIPS Lawrence Livermore National Laboratory, L-219, Livermore CA 94550 USA

\section{ABSTRACT}

Predictions of long-term glass dissolution rates are highly dependent on the form of the affinity term in the rate expression. Analysis of the quantitative effect of saturation state on glass dissolution rate for CSG glass (a simple analog of SRL-165 glass), shows that a simple $(1-Q / K)$ affinity term does not match experimental results. Our data at $100^{\circ} \mathrm{C}$ show that the data is better fit by an affinity term having the form $\left(1-\left(\frac{Q}{K}\right)^{\frac{1}{\sigma}}\right)$ where $\sigma=10$.

INTRODUCTION

In a closed system, the rate of borosilicate waste glass dissolution decreases with time due to the approach of the solution composition to glass saturation. This conclusion is based on analysis of numerous glass dissolution experiments performed over several decades ${ }^{1}$. Although transport limited dissolution is sometimes observed, it appears not to be important in most long-term tests. Because silica is the major component of glass, dissolved silica concentration correlates well with the decrease in reaction rate and has been used to predict glass dissolution rates. ${ }^{2}$

The saturation effect is incorporated in current rate expressions for glass dissolution as the term $(1-Q / K)$ where $Q$ is the ion activity product for the glass dissolution reaction and $K$ is the solubility product for glass written in the same way as the expression for $Q$. As species build up in solution, the value of $Q$ increases and the term approaches a value of zero at saturation. The affinity term has its origin in the rigorously-derived rate law 3,4

$$
\left(\frac{d n}{d t}\right)=S k_{+} \prod_{i} a_{i}^{-n}(1-\exp (-A / \sigma R T))
$$

where $S$ is surface area, $k$ is the rate coefficient, $a_{i}$ are the aqueous solution species activities, $A$ is the reaction affinity, $\sigma$ is the average stoichiometric number for the reaction, $R$ the gas constant and $T$ the temperature in Kelvin.

Because reaction affinity $(A)$ is defined as $A=R T \ln (Q / K)$, Eqn. 1 can be simplified and re-arranged to give:

$$
\left(\frac{d n}{d t}\right)=S k(p H)\left(1-\left(\frac{Q}{K}\right)^{1 / \sigma}\right)
$$


where now all solution compositional dependencies of the rate coefficient other than $\mathrm{pH}$ are ignored.

Kinetic rate theory does not predict the form of the affinity term in the rate equation. In fact, there may be one or more exponential terms on the factor which can be written in a more general form as:

$$
\left(1-\left(\frac{Q}{K}\right)^{\frac{1}{\sigma}}\right)^{\nu}
$$

where $1 / \sigma$ and $v$ are exponents which must be determined experimentally. Transition state theory predicts a form where $v=1$ and $\sigma$ is some real number. In transition state theory, $\sigma$ is defined as the average stoichiometric number, which gives the rate of the rate limiting reaction step relative to the overall rate ${ }^{3}$. The nonlinear case where $v \neq 1$ is also possible.

In order to better constrain the affinity term in our rate equation for glass dissolution, we have used the results of closed system dissolution tests of CSG glass (in wt \%; 18.2 $\mathrm{Na}_{2} \mathrm{O}, 6.0 \mathrm{CaO}, 11.7 \mathrm{Al}_{2} \mathrm{O}_{3}, 8.4 \mathrm{~B}_{2} \mathrm{O}_{3}, 55.7 \mathrm{SiO}_{2}$ ) at $1000 \mathrm{C}$ in a dilute ( 0.003 molal) sodium bicarbonate solution to calculate values of the affinity term in the rate equation. This carbonate solution has approximately the same $\mathrm{pH}$ and $\mathrm{pH}$ buffer capacity as J-13 well water at the Yucca Mountain potential repository site but, because it has only one dissolved salt, it simplifies analysis of the dissolved species data. Analysis of how the affinity term changes with reaction progress should allow us to constrain the functional form of the affinity term.

\section{METHODS AND ANALYSIS}

Closed system tests of CSG glass at 1000 C show nearly stoichiometric release of $\mathrm{Si}, \mathrm{B}$, $\mathrm{Al}$, and $\mathrm{Ca}$ until about 30 days (Fig. 1). After 30 days $\mathrm{Ca}$ concentrations decrease, probably due to calcite precipitation. Analysis of the solutions at 30 days show supersaturation with respect to both calcite and calcium zeolites. However, the glass is probably still dissolving stoichiometrically. Resolution of $\mathrm{Na}$ release rate (not plotted) was poor because it was present in the leachate.

The rate of release of elements from the glass is given by the slope of the elemental release curves in Fig. 1. Therefore we use data for the fastest released element (silica in this case) and calculate the derivative at each of data point (Fig. 2). The derivative curve gives the glass dissolution rate as a function of time. The form of this curve should therefore match the form predicted by the affinity term in the rate equation.

Two corrections must first be made to the silica release rate data before the analysis. In our closed-system experiments, the total volume of the system decreases as samples are withdrawn. Therefore the rate of increase of dissolved silica concentration must be corrected for the progressively smaller solution volume into which it is dissolving (see Table 1). The second correction is for the pH effect on the rate coefficient. Other experiments have shown that the rate coefficient for CSG glass increases with $a_{H^{+}}-0.4$ As the glass dissolves, the $\mathrm{pH}$ rises from 7.9 to 8.6 , which increases the value of the rate coefficient by a factor of 1.4. Applying both these corrections results in the silica release rate curve shown in Fig. 3. We also assume 
that at these $\mathrm{pH}$ and temperature conditions, total silica is approximately equal to the concentration of uncharged and unpolymerized $\mathrm{SiO}_{2}(\mathrm{aq})$.

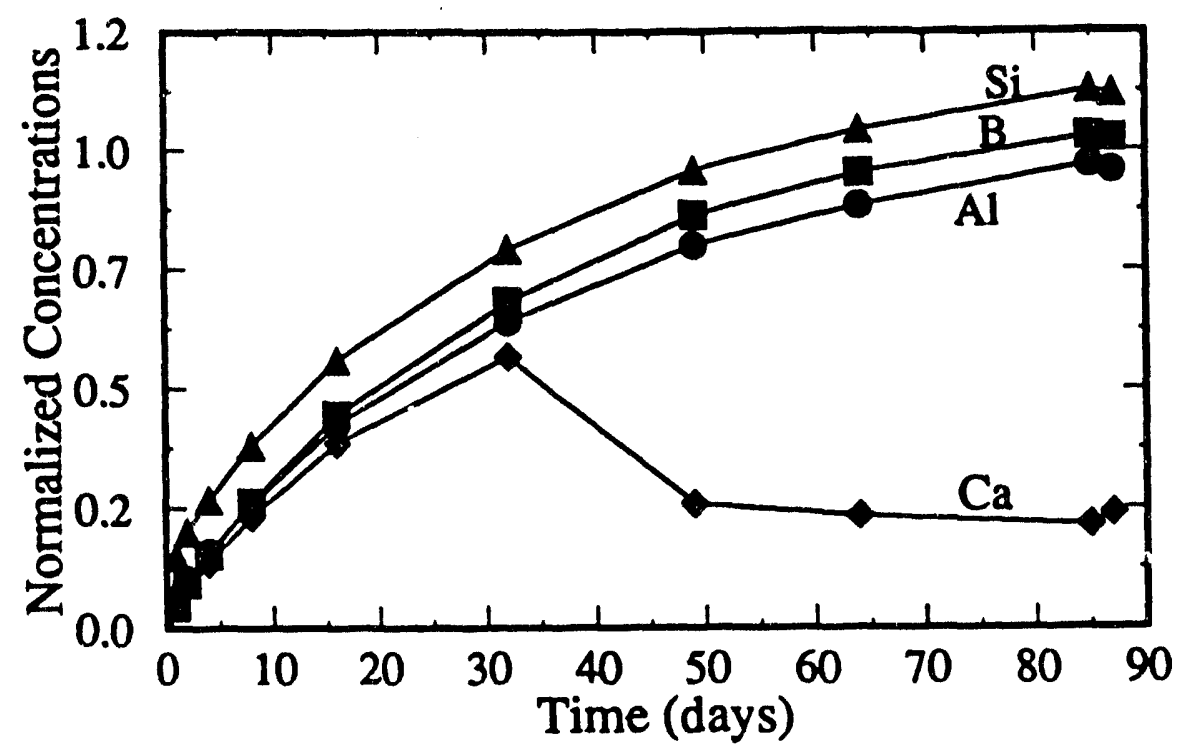

Figure 1. Normalized elemental concentrations vs. time for CSG glass dissolving at $100^{\circ} \mathrm{C}$ in $.005 \mathrm{~m} \mathrm{NaHCO} 3$ solution.

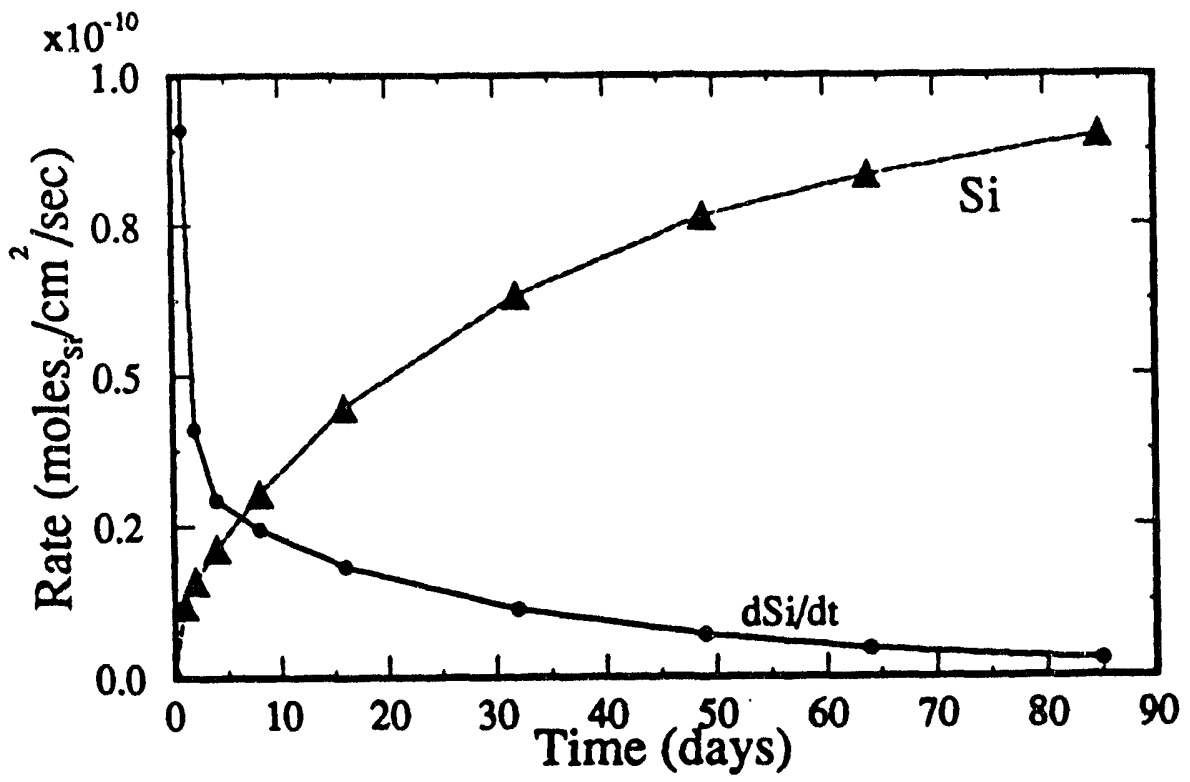

Figure 2. Cumulative and derivative Si release from CSG glass at $100^{\circ} \mathrm{C}$.

The form of the affinity term is a function of both the value of $K$ used in the expression, and the values of the exponents in the affinity term. The value of $K$, the equilibrium constant for the dissolving solid, depends on two assumptions: (1) the solid assumed to be controlling dissolution rate; and (2) the thermodynamic model chosen for that solid. Potential solids that could be rate controlling include the anhydrous glass, the hydrous alkali-depleted surface gel layer of the glass, and a simple silica phase, depending on what specific reaction is rate controlling. Earlier modeling results 5,6 showed that the anhydrous glass is too thermodynamically 
unstable to be the rate controlling phase. The value of $\mathrm{K}$ for the glass is so large that the ratio $Q / K$ never approaches one. The value of $(1-Q / K)$ therefore never gets significantly smaller than one and the model predicts no decrease in rate as species such as silica build up in solution. This contrasts with the experimental data.

For this analysis, we have assumed that it is the saturation of a simple silica phase which is rate controlling ${ }^{2}$. The experimental data will be used to estimate the thermodynamic stability of the hypothetical silica phase. The use of more complex solids, such as the surface gel layer, did not provide sufficient improvement in the fit of the experimental data to warrant its continued use in this analysis.

Table 1. Measured and corrected normalized CSG glass dissolution rates.

\begin{tabular}{|ccccccc|}
\hline Day & $\begin{array}{c}\text { Measured } \\
\text { Release } \\
\text { Rate }\end{array}$ & $\mathrm{pH}$ & $\begin{array}{c}\text { Rate } \mathrm{k}(\mathrm{pH}) \\
\text { factor }\end{array}$ & $\begin{array}{c}\text { Volume of } \\
\text { Fluid }\end{array}$ & $\begin{array}{c}\text { Volume of } \\
\text { Fluid Factor }\end{array}$ & $\begin{array}{c}\text { Corrected } \\
\text { Release } \\
\text { Rate }\end{array}$ \\
\hline 0 & 1 & 7.88 & & 213.3 & 1.00 & $1.00 \mathrm{E}+00$ \\
1 & 0.5 & 7.88 & 1 & 199.6 & 0.94 & $4.68 \mathrm{E}-01$ \\
2 & 0.22 & 8.04 & 0.95 & 185.5 & 0.87 & $1.82 \mathrm{E}-01$ \\
4 & 0.16 & 8.04 & 0.95 & 171.5 & 0.80 & $1.22 \mathrm{E}-01$ \\
8 & 0.13 & 8.15 & 0.92 & 158.8 & 0.74 & $8.90 \mathrm{E}-02$ \\
16 & 0.1 & 8.26 & 0.88 & 146.6 & 0.69 & $6.05 \mathrm{E}-02$ \\
32 & 0.06 & 8.45 & 0.79 & 133.9 & 0.63 & $2.98 \mathrm{E}-02$ \\
49 & 0.04 & 8.48 & 0.77 & 120.7 & 0.57 & $1.74 \mathrm{E}-02$ \\
64 & 0.026 & 8.49 & 0.77 & 107.9 & 0.51 & $1.01 \mathrm{E}-02$ \\
85 & 0.015 & 8.56 & 0.71 & 94.7 & 0.44 & $4.73 \mathrm{E}-03$ \\
\hline
\end{tabular}

Once we have selected a thermodynamic model for the rate controlling solid, we can investigate the form of the affinity expression. Fig. 3 compares our measured rate (solid squares) with calculated values for the affinity term. The curve with solid triangles shows the values for the term $(1-Q / K)$ where $\log K$ is -3.1 . Comparison of the measured and calculated rates indicates that the saturation effect is appreciable much further from equilibrium than the simple $(1-Q / K)$ term predicts. Even if the value of $\mathrm{K}$ is decreased to force the curve toward the experimental data (curve with open boxes in Fig. 3), the agreement is poor and rate equation predicts glass precipitation after 20 days. A different functional form is necessary to match the observed rates.

If we regress the experimental data to a function of the form shown in Eqn. 3, set $v=1$, and regress in terms of $K$ and $\sigma$ we get values of -3.1 for $K$ and 10 for $\sigma$. The curve marked with solid diamonds shows the good agreement between this curve and the experimental data.

\section{DISCUSSION AND CONCLUSIONS}

Previous workers have analyzed dissolution rates of solids close to saturation and found deviations from behavior which follows the $(1-Q / K)$ term. Jorgensen ${ }^{7}$ found that amorphous silica precipitation and dissolution follows a trend given by (1$\mathrm{Q} / \mathrm{K})^{3}$. Experimental measurements of calcite $\left(\mathrm{CaCO}_{3}\right)$ precipitation/dissolution follow a form of $(1-Q / K)^{n}$ where $n$ commonly ranges from 2.7 to 4.3 , but was as large as 17 in one study ${ }^{8}$. Nagy and co-workers ${ }^{9}$ found that dissolution of kaolinite $\left(\mathrm{Al}_{2} \mathrm{Si}_{2} \mathrm{O}_{5}(\mathrm{OH})_{4}\right)$ followed a rate law given by $\left(1-\left(\frac{Q}{K}\right)^{.25}\right)$, whereas Burch and others 
10 found that albite followed a similar expression with an exponent of 0.73 instead of 0.85. Rimstidt and Barnes ${ }^{11}$ were able to fit their experimental data for various silica polymorphs to a simple $(1-\mathrm{Q} / \mathrm{K})$ expression. Behavior which follows a simple (1$Q / K)$ affinity expression appears to be rather uncommon among existing experimental dissolution rate data, so our data is not unique in that respect.

A mechanistic interpretation of our results is not yet possible. More detailed information on the microscopic rate limiting reaction mechanism is needed. This information will become available as further work is performed on characterizing the solution-glass interface through macroscopic techniques such as surface titrations, and through spectroscopic examination of both the reacted and unreacted glass.

In future work we will model additional experimental results for different glasses using our modified affinity term function to determine how generally applicable this model is. The mathematical form of the affinity term is clearly of great importance in extrapolating our test results to long time periods and must be accurately defined for justifiable long-term predictions of glass dissolution rates to be made.

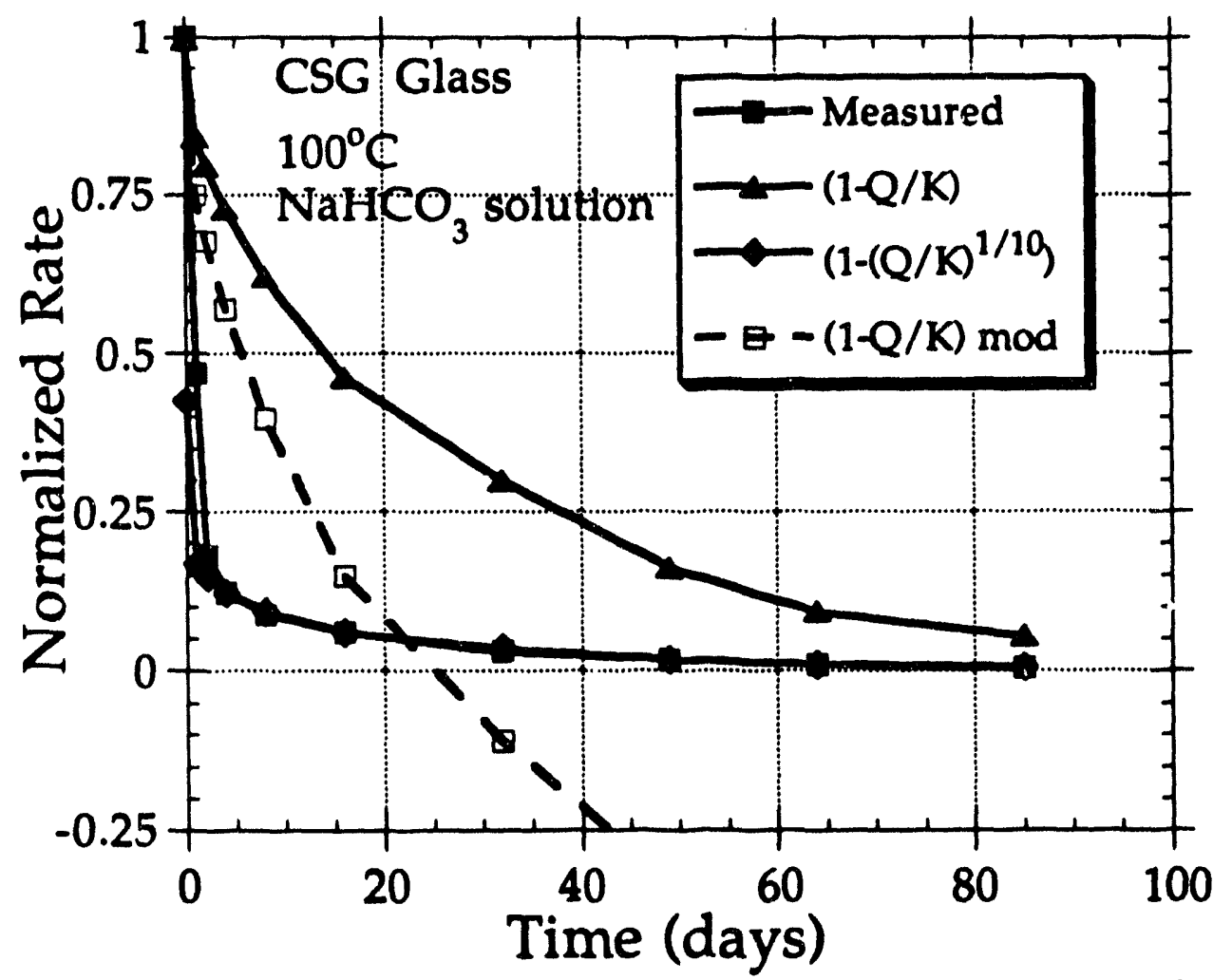

Figure 3. Measured and computed normalized rate of glass dissolution based on three different affinity expressions (see text).

\section{ACKNOWLEDGMENTS}

This work was supported by the U.S.D.O.E. Office of Environmental Restoration and Waste Management, under contract W-31-109-ENG-38 through Argonne National Laboratory. Work was performed under the auspices of the U.S. Department of Energy by Lawrence Livermore National Laboratory under contract number W-7405ENG-48. 
REFERENCES

(1) High-level waste borosilicate glass: a compendium of corrosion characteristics.; J.C. Cunnane, Ed.; Argonne National Laboratory (in press), 1993.

(2) B. Grambow, "Nuclear waste glass dissolution: Mechanism, model and application.", JSS Project, Swedish Nuclear Fuel and Waste Management Co., 8702, (1987).

(3) P. Aagaard and H.C. Helgeson, Am. J. Science, 282, 237-285 (1982).

(4) K.G. Knauss, W.L. Bourcier, K.D. McKeegan, C.I. Merzbacher, S.N. Nguyen, F.J. Ryerson, D.K. Smith, H.C. Weed and L. Newton, Mat. Res. Soc. Symp. Proc., 176, 371-381 (1990).

(5) W.L. Bourcier, "Geochemical modeling of radioactive wasteglass dissolution using EQ3/6: Preliminary results and data needs", Lawrence Livermore National Laboratory, UCID-21869, (1989).

(6) T. Advocat, J.L. Crovisier, B. Fritz and E. Vernaz, Mat. Res. Soc. Symp. Proc., 176, 241-248 (1990).

(7) S.S. Jørgensen, Acta Chem. Scandinavia, 22, 335-341 (1968).

(8) U. Svensson and W. Dreybrodt, Chem. Geol., 100, 129-145 (1992).

(9) K.L. Nagy, A.E. Blum and A.C. Lasaga, Am. J. Science, 291, 649-686 (1991).

(10) T.E. Burch, K.L. Nagy and A.C. Lasaga, Chem. Geol., 105, 137-162 (1993).

(11) J.D. Rimstidt and H.L. Barnes, Geochim. Cosmochim. Acta, 44, 1683-1699 (1980).

6 

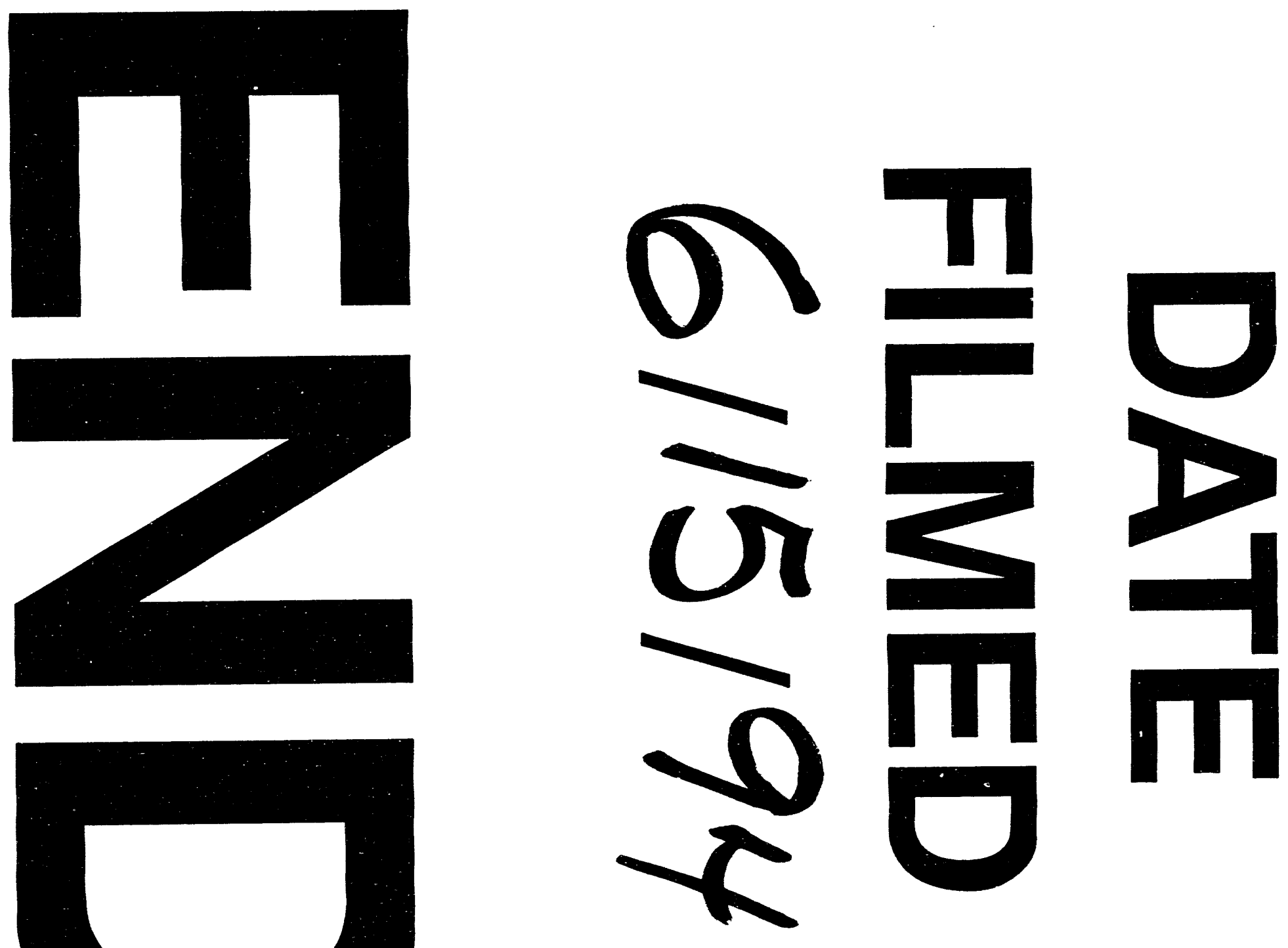


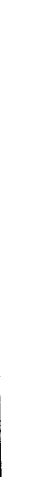

